\title{
尿路性器悪性腫瘍患者における尿中ネオプテリン值の検討
}

\author{
防衛医科大学校泌尿器科学講座 \\ 浅野 友彦 中島 史雄 小田島邦男 \\ 过明早川正道 中村宏

\section{URINARY NEOPTERIN LEVELS IN PATIENTS WITH GENITOURINARY TRACT MALIGNANCIES}

\author{
Tomohiko Asano, Fumio Nakajima, Kunio Odajima, Akira Tsuji, \\ Masamichi Hayakawa and Hiroshi Nakamura \\ Department of Urology, National Defense Medical College
}

(Background) Neopterin is released from macrophages upon stimulation with $\gamma$-interferon, secreted by activated $\mathrm{T}$ cell. Therefore it has been recognized as a useful indicator of the activation of the $\mathrm{T}$ cell-macrophage system. Increased neopterin levels are observed in patients with acute graft rejections, viral infections, auto-immune diseases and several malignancies. Urinary neopterin concentrations were determined in patients with genitourinary tract malignancies to evaluate the usefulness of neopterin as a tumor marker.

(Methods) Urinary neopterin concentrations were determined by high-performance liquid chromatography in 90 patients with genitourinary tract malignancies and 28 patients with benign urological tumors and 34 healthy subjects.

(Results) Increased urinary neopterin levels were observed in $52 \%$ of the patients with genitourinary tract malignancies and $7 \%$ with benign urological tumors. The positivity rate in patients with renal cell carcinoma (RCC), renal pelvic and ureteral tumor, bladder tumor (BT), prostatic carcinoma (PC) and testicular tumor was $68 \%, 80 \%, 47 \%$ and $30 \%$, respectively. The difference in the urinary neopterin levels between low and high stages was highly significant $(\mathrm{p}<$ 0.0005 ) in patients with RCC (stage I-II vs. stage III-IV) and BT ( $\mathrm{T}_{\mathrm{is}-1}$ vs. $\mathrm{T}_{2-4}$ ). The urinary neopterin levels were also correlated with the tumor grade in patients with RCC and PC.

(Conclusion) Our study suggests that urinary neopterin levels may supplement laboratory examinations for patients with genitourinary tract malignancies, providing useful information in evaluating the tumor stage and follow-up of the disease.

Key words: neopterin, genitourinary tract malignancy, tumor marker

要旨：(背景と目的) ネオプテリンは, 活性化された $\mathrm{T}$ 細胞から分泌される $\gamma$-インターフェロンの刺激 によりマクロファージから放出が増加することが知られており， T 細胞一マクロファージ系の活性化の 指標とされている。 そのため, ネオプテリンは, 拒絶反応, ウイルス感染症, 自己免疫疾患, 癌患者で 上昇することが報告されている，今回，尿路性器悪性腫瘍患者の尿中ネオプテリンを測定し，腫瘍マー カーとしての有用性について検討を加えた。

（方法）尿路性器悪性腫瘍患者 90 名, 泌尿器科良性腫瘍患者 28 名, 正常健康人 34 名における尿中ネ才 プテリン濃度を高速液体クロマトグラフィーを用いて測定した。

（結果）尿路性器悪性腫瘍患者の $52 \%$ ，泌尿器科良性腫瘍患者の $7 \%$ \%いて尿中ネオプテリン值は 増加していた。陽性率は, 腎細胞癌患者 $68 \%$, 腎孟尿管癌患者 $80 \%$, 膀胱癌患者 $44 \%$, 前立腺癌患者 $47 \%$, 精巣腫瘍患者 $30 \%$ あった. low stage 群と high stage 群を比較すると, 腎細胞癌患者（stage I, II vs. stage III，IV）及び膀胱癌患者（Tis-1 vs. T2-4）で両群間の尿中ネオプテリン值に有意（p<0.0005） 
に差を認めた。腎細胞癌患者及び前立腺癌患者では，尿中ネオプリテン值と異型度との間に相関を認め た。

（結論）今回の検討の結果，尿中ネオプテリン值は，尿路性器悪性腫瘍患者における腫瘍の進展度の 把握や経過観察に有用であると思われた。

キーワード：ネオプテリン，尿路性器悪性腫瘍，腫場マーカー

\section{緒 言}

tetrahydrobiopterin (THB) は, guanosine triphosphate (GTP) から GTP cyclohydrolase によって誘 導される物質であり，ドパミンやセロトニンなどの神 経伝達物質を合成する際に co-factor として必要とさ れるものである.したがって, GTP cyclohydrolase は 本来神経組織に多く分布するものであるが，その他に もマクロファージや線維芽細胞にも存在するとされて いる.そしてマクロファージに含まれる GTP cyclohydrolase 活性は, 各種サイトカイン, 特に $\gamma$-インター フェロン $(\gamma$-IFN $)$ によって著明に増強されることが知 られている ${ }^{1)}$ ネオプテリンは, GTP から THB が合 成される際に生ずる中間代謝産物であるが，生体内に おいてサイトカインの分泌が充進している病態におい てその産生が妄進する.このためネオプテリンは，生 体における免疫賦活状態, 特に T 細胞一マクロファー ジ系の活性化状態を知る指標として, 移植後拒絶反 応 $^{2)}$, 感染症 ${ }^{3)}$, 自己免疫疾患 ${ }^{4}$ 等の診断や活動性の判定 に臨床的に応用されている。また，各種悪性腫瘍患者 においてもネオプテリンの産生が増加していることが
報告されている ${ }^{5 / 6)}$ が, 今回我々は尿路性器悪性腫瘍患 者の尿中ネオプテリンを測定し, 各種悪性腫瘍の進行 度，異型度との関連について検討を加えたので報告ず る.

\section{対象及び方法}

病理組織学的に診断が確認された尿路性器悪性腫瘍 患者90名（腎細胞癌19名，腎孟尿管癌10名，膀胱癌 32 名, 前立腺癌19名, 精巣腫瘍 10 名), 良性腫瘍患者 28 名 (前立腺肥大症 23 名, 副腎腺腫 5 名), 正常健康人 34 名 を対象とした。

患者の早朝第一尿を $10 \mathrm{ml}$ 採取し, disodium ethylenediamine tetraacetate $100 \mathrm{mg}$ を加え, 測定まで一 $20^{\circ} \mathrm{C}$, 暗所に冷凍保存し, 測定直前に溶解し, Sep-Pak $\mathrm{C}_{18}$ cartridge で固形物質や, 非極性物質を吸着除去し た後，測定に用いた。

ネオプテリンは, Hausen らの方法に従って測定し た。すなわち，高速液体クロマトグラフィー(Varian Model LC 5100）を用い， $300 \times 3.9 \mathrm{~mm}$ のステンレス カラムに $10 \mu \mathrm{m}$ Bonda-pak $\mathrm{C}_{18}$ を充填したカラムでネ オプテリンとクレアチニンの分離を行った。 ネオプテ

図 1 正常健康人, 尿路性器悪性腫瘍患者, 泌尿器科良性腫瘍患者の尿中ネオプテリ ン值

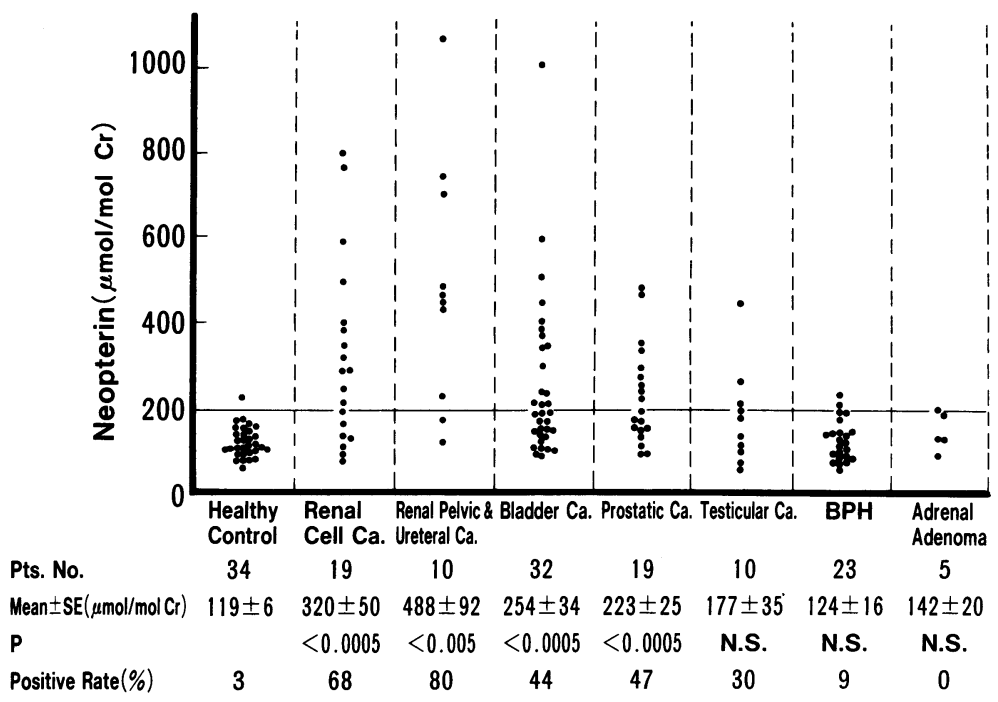


図 2 腎細胞癌患者の stage 別尿中ネオプテリン值

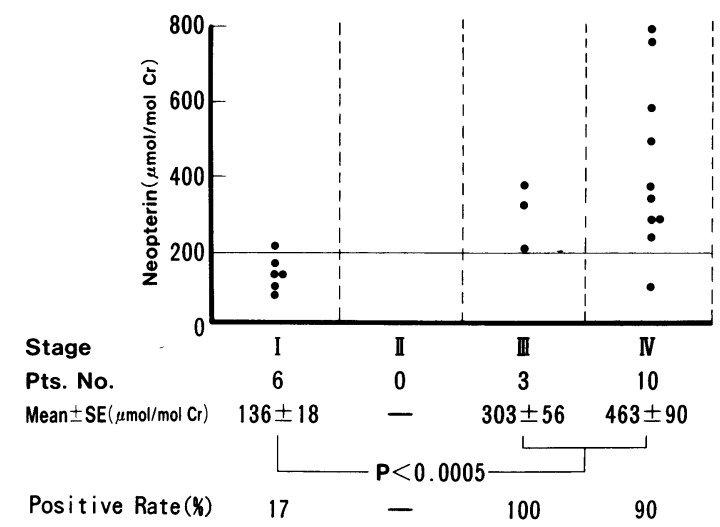

図 3 腎細胞癌患者の grade 別尿中ネオプテリン值

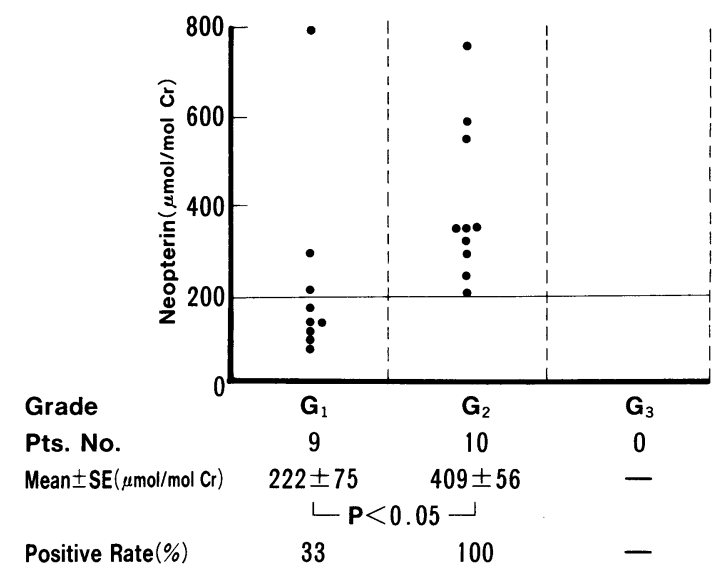

リンは, 蛍光分光光度計(日立 F1000)を用い, 励起波 長 $353 \mathrm{~nm}$, 蛍光波長 $438 \mathrm{~nm}$ にて測定した。クレアチニ ンは，紫外分光光度計（Varian UV200）を用い，235 $\mathrm{nm}$ での吸光度で測定した. 尿の濃縮や, 希釈による尿 中ネオプテリン濃度の変動を取り除くために尿中ネオ プテリン濃度を尿中クレアチニン濃度で除した值を尿 中ネオプテリン值 $(\mu \mathrm{mol} / \mathrm{molCr})$ として検討を加え た.

\section{結 果}

1. 正常健康人 (図 1 ) : 正常健康人 34 名 (年齢 $25 \sim 72$ 歳, 平均44.3歳, 男性20名, 女性14名）の尿中ネオプ テリン值は, $119 \pm 36(\mathrm{mean} \pm \mathrm{SD}) \mu \mathrm{mol} / \mathrm{molCr}$ であっ た。正常健康人の尿中ネオプテリン值の mean $+2 \mathrm{SD}$ にあたる $191 \mu \mathrm{mol} / \mathrm{molCr}$ を正常上限值に設定し, こ れを越えるものを陽性と判定した。この場合の正常健 康人の陽性率は $3 \%$ \%ちった。
図 4 膀胱癌患者の stage 別尿中ネオプテリン值

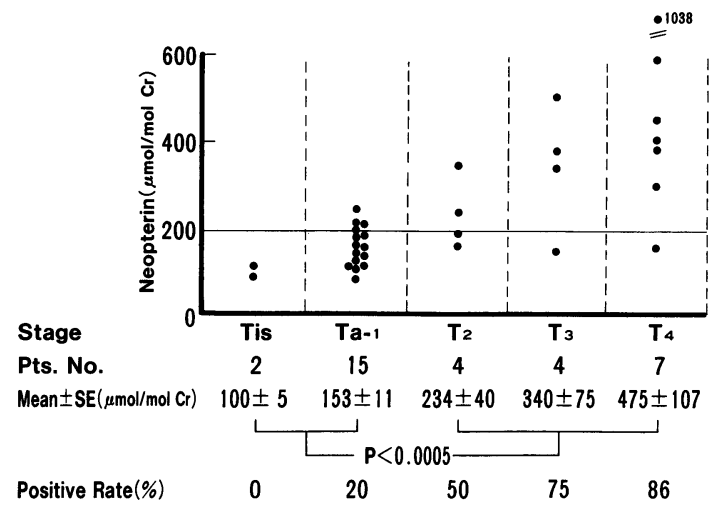

2. 腎細胞癌患者（図 2,3 ）：腎細胞癌患者の尿中 ネオプテリン值は, $320 \pm 50(\mathrm{mean} \pm \mathrm{SE}) \mu \mathrm{mol} / \mathrm{molCr}$ であり, 正常健康人と比べて有意 $(\mathrm{p}<0.0005)$ に高值 を示し，陽性率は68\%であった. Stage 別(Robson 分 類）の尿中ネオプテリン值は, stage I ( 6 名), 136土 $18 \mu \mathrm{mol} / \mathrm{molCr}$, stage III ( 3 名) $303 \pm 56 \mu \mathrm{mol} / \mathrm{molCr}$, stage IV (10名) $463 \pm 90 \mu \mathrm{mol} / \mathrm{molCr}$ であり, stage が高くなるほど高値を示し, stage I, IIを low stage 群， stage III，IVを high stage 群とすると high stage 群は low stage 群に比べて有意 $(\mathrm{p}<0.0005)$ に高值を 示した。異型度別（腎癌取扱い規約）では G3の患者は なく G1 (9 名), G2（10名）群の尿中ネオプテリン值 は, 各々 $222 \pm 75,409 \pm 56 \mu \mathrm{mol} / \mathrm{molCr}$ と異型度が強 くなるほど高值を示した $(\mathrm{p}<0.05)$.

3. 腎孟尿管癌患者（図 1 ）：腎孟尿管癌患者 10 名の 尿中ネオプテリンの平均值は, $488 \pm 92 \mu \mathrm{mol} / \mathrm{molCr}$ であり, 正常健康人と比べて有意 $(\mathrm{p}<0.005)$ に高值 を示し，陽性率は $80 \%$ であった。

4. 膀胱癌患者 (図 4,5 ) : 膀胱癌患者 32 名の尿中 ネオプテリン值の平均値は, $254 \pm 34 \mu \mathrm{mol} / \mathrm{molCr}$ で あり, 正常健康人と比べて有意 $(\mathrm{p}<0.0005)$ に高値を 示し, 陽性率は $44 \%$ であった。深達度別（膀胱癌取扱 い規約) では, Tis, Ta-1, T2, T3, T4で各々 $100 \pm$ $5,153 \pm 11,234 \pm 40,340 \pm 75,495 \pm 107 \mu \mathrm{mol} / \mathrm{molCr}$ と深達度が深くなるほど高値を示し, Tis, Ta-1を非浸 潤群，T2，T3，T4を浸潤群とすると浸潤群は非浸潤群 に比べて有意 $(\mathrm{p}<0.0005)$ に高值を示した. 異型度別 （膀胱癌取扱い規約）では，G1群で171 $130, \mathrm{G} 2$ 群で $251 \pm 41, \mathrm{G} 3$ 群で $351 \pm 109 \mu \mathrm{mol} / \mathrm{molCr}$ と異型度が強 くなるほど高值を示したが有意差は認められなかっ た. 
図 5 膀胱癌患者の grade 別尿中ネオプテリン值

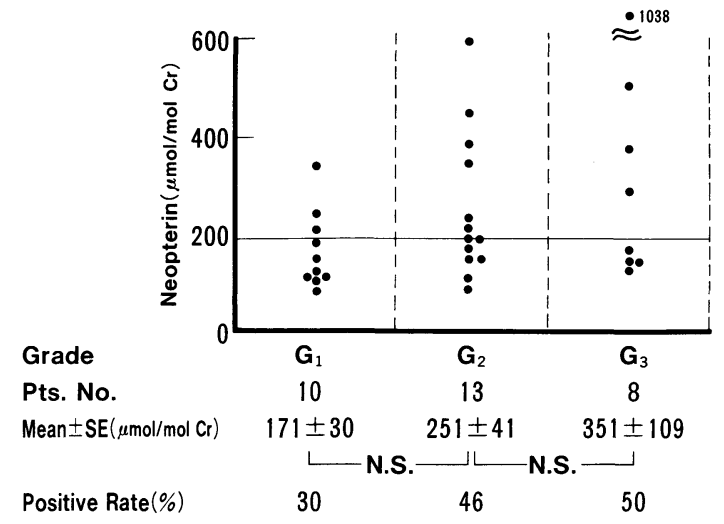

5. 前立腺癌患者（図 1 ）：前立腺癌患者全体の尿中 ネオプテリン值の平均は, $223 \pm 109 \mu \mathrm{mol} / \mathrm{molCr}$ であ り，正常健康人と比べて有意 $(\mathrm{p}<0.0005)$ に高值を示 し，陽性率は47\%であった. Stage 別(前立腺癌取扱い

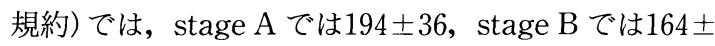
27, stage Cでは293, stage D では $252 \pm 43 \mu \mathrm{mol} /$ molCr であり, 各 stage 間で差は認められなかった。

異型度別では, 高分化型 $142 \pm 27$, 中分化型196 \pm 16 , 低分化型 $392 \pm 47 \mu \mathrm{mol} / \mathrm{molCr}$ と異型度の大きいもの ほど高値を示し, 中分化型は高分化型に比べ有意 $(\mathrm{p}<$ 0.005)に，また低分化型は中分化型に比べて有意 $(\mathrm{p}<$ 0.005）に高値を示した。

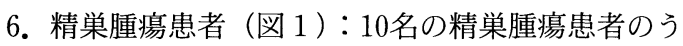
ち, stage 別 (日本泌尿器科学会病期分類)では, stage I 6 名, stage II 3 名, stage III 1 名で, 組織型は seminoma 6 名, non-seminoma 4 名であった. 尿中ネ オプテリン值の平均は, $177 \pm 35 \mu \mathrm{mol} / \mathrm{molCr}$ であり, 正常健康人と比べて有意差は認められなかった。各 stage 間, 及び両組織型間で尿中ネオプテリン值の差 は認められなかった。

7. 泌尿器科領域の良性腫場患者（図 1)：前立腺肥 大症 23 名, 副腎腺腫 5 名の尿中ネオプテリン值は, 各久 $124 \pm 16,142 \pm 20 \mu \mathrm{mol} / \mathrm{molCr}$ と正常健康人と比べて 有意差は認められず，陽性率は各々 $9 \% ， 0 \%$ あっ た.

\section{考 察}

癌細胞に対して宿主の免疫応答がひきおこされるメ カニズムとしては,まず抗原提示細胞 (Antigen Presenting Cell：APC) が癌細胞の腫瘍関連抗原 (Tumor Associated Antigen : TAA) をとりこみ,こ れを $\mathrm{T}$ 細胞に提示することで $\mathrm{T}$ 細胞系が活性化され
るとする説が現在のところ有力である，このときに， 活性化されたへルパーT 細胞からインターロイキン 2 や $\gamma$-IFN などのサイトカインが分泌されるが, 実際 にも悪性腫場患者において $\gamma$-IFN の血中濃度が上昇 しているという報告もみられる819). しかしながら， $\gamma$-IFN は産生される量が微量であり, 半減期が短く, 細胞や蛋白に付着するため, 腫瘍マーカー, あるいは 免疫状態のモニタリングの手段としては有用ではない とされている.一方, ネオプテリンは, $\gamma$-IFN の刺激 によりマクロファージからの分泌が増加するが, 血中, 尿中に扔いても比較的安定しており, T 細胞一マク口 ファージ系の活性化状態を間接的に知る指標として有 用であるとされている。

今回, 各種尿路性器悪性腫瘍患者 90 名の尿中ネオプ

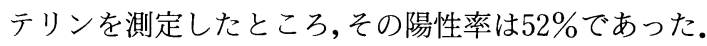
尿路性器悪性腫瘍患者のネオプテリンについては, Fuchs $^{10)}$, Kuzmitz $^{11)}$ らの報告があるが, その陽性率は 各々 $54 \% ， 55 \%$ と著者らの成績とほぼ同様であった。 我々の検討では, 悪性腫瘍の進展度が高くなるほどネ オプテリンは高值を示し, 腫瘍の進行度を把握するの に有用であると思われた。特に膀胱癌患者においては, T2-4群は Tis-1群と比べて有意 $(\mathrm{p}<0.0005)$ に高く, 腫瘍の筋層浸潤の有無を判定するのに有用であると思 われた. Aulitzky ら ${ }^{12)}$ も，同様な成績を報告しており， 腫瘍細胞が lamina propria を越えて浸潤性になった ときに T 細胞一マクロファージ系が賦活化されネオ プテリンが上昇するからではないかと推察している. また, 膀胱癌患者と比べて同じ移行上皮癌である腎孟 尿管癌患者で尿中ネオプテリン值の陽性率が $80 \%$ と高 かったのは, 10名中 8 名が stage III, IVと high stage の患者が多かったためと思われる。一方, 前立腺癌患 者では, stage D患者10名のうち 5 名で尿中ネオプテ リン值は正常範囲内にあり, 進展度による差がみられ なかった。これら 5 名中 3 名はすでにホルモン療法を 受けており，他の腫瘍マーカーも正常化していたため と思われる。

組織学的異型度別にみてみると, 腎細胞癌患者, 前 立腺癌患者で異型度が高くなるほど尿中ネオプテリン 値は高值を示す傾向がみられた。しかしながら，異型 度の高い腫瘍は進展度が進んでいることが多く, ネオ プテリンが異型度と進展度のどちらにより影響を受け ているのかは明かではなかったが, 同一の進展度の患 者間で比較すると異型度によるネオプテリンの差はほ とんどみられなかったため, 異型度よりは進展度に影 
響を受けるのではないかと思われた。

ネオプテリンと患者の予後との関連については，ネ オプテリンが高い患者では病期や異型度にかかわらず 予後が不良であるとの報告が多い13)14)，著者らの検討 でも腎細胞癌患者において, 尿中ネオプテリン值, 病 期, 異型度, 腫瘍径などを多変量解析を用いて分析し たところ，これらの因子の中では尿中ネオプテリン值 が最も長期予後と相関することが明らかとなった ${ }^{15)}$. 癌患者においてネオプテリンが上昇しているというこ とは， $\gamma$-IFN によりマクロファージが刺激されている 状態を示すが，このことは必ずしも有効に細胞障害性 T細胞や，マクロファージ等のエフェクター細胞が産 生されていることを示しているわけではない ${ }^{16)}$.逆に, $\gamma$-IFN により活性化されたマクロファージが, TGF- $\alpha$ などの腫瘍増殖因子や，血管造成因子を放出したり， あるいは活性化されたマクロファージのうちのサプ レッサー・マクロファージが腫瘍局所で免疫抑制的に 作用しているため，ネオプテリンが高值を示す患者の 予後が悪いのではないかとする報告もある ${ }^{17)}$.一方, 亲 オプテリンやその代謝産物が免疫系に及ぼす影響はほ とんどないとされており，ネオプテリンが直接免疫を 抑制している可能性は少ないと考えられている ${ }^{18)}$.ま た, 癌が活動性であるときに血中の $\gamma$-IFN が上昇する

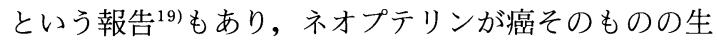
物学的活性を反映している可能性もある.

感度については, 進展度の高い腫瘍では陽性率が高 く，進展度の把握や治療効果のモ二ターとしては有用 であると思われたが, 早期癌におけるネオプテリンの 陽性率は低く，スクリーニング上，最も意義のある早 期癌の発見の手段としての有用性は認められなかっ た.

また，ネオプテリンの特異性に関しては，正常健康 人や良性腫瘍患者（前立腺肥大症, 副腎腺腫）におけ る陽性率が各々 $3 \% ， 7 \%$ と低く, 特異性は高かった。 しかしながら, T細胞一マクロファージ系の賦活化さ れる自己免疫疾患, ウイルス感染症, 結核などのとき にも上昇するとの報告があり, 悪性腫瘍を評価する際 には臨床経過や他の検査所見も注意深く察観し, これ らの疾患の合併の有無を確認しておく必要があると思 われる。また，著者らの経験では，急性腎孟腎炎にお いても尿中ネオプテリン值が上昇するので尿路感染症 の有無についても調べておく必要がある.

尿中ネオプテリン值は, 尿路性器悪性腫瘍患者にお いてスクリーニングの手段としての有用性は認められ
なかったが，特異度は十分に高く，また進行した腎細 胞癌患者, 膀胱癌患者においては腫瘍の進展度の把握 に有用であると思われた。

\section{文献}

1) Huber, C., Batchelor, J.R., Fuchs, D., Hausen, A., Lang, A., Niederwieser, D., Reibnegger, G., Swetly, P., Troppmair, J. and Wachter, H. : Immune response-associated production of neoptein. J. Exp. Med., 160, 310-316, 1984.

2) Woloszczuk, W., Troppmair, J., Leiter, E., Flener, R., Schwarz, M., Kovarik, J., Pohanka, E., Margreiter, R. and Huber, C. : Relationship of interferon- $\gamma$ and neoptein levels during stimulation with alloantigens in vivo and in vitro. Transplantation, 41, 716-719, 1986.

3) Fuchs, D., Hausen, A., Kofler, M., Kosanowski, H., Reibnegger, G. and Wachter, H. : Neopterin as an index of immune response in patients with tuberculosis. Lung, 162, 337-346, 1984.

4) Lim, K.L., Muir, K. and Powell, R.J.: Urine neopterin : A new parameter for serial monitoring of disease activity in patients with systemic lupus erythematosus. Ann. Rheum. Dis., 53, 743 $-748,1994$.

5) Zitko, M., Andrysek, O. and Cernovska, M. : Renal excretion of neopterin and biopterin in patients with malignant melanoma and Hodgkin's disease. 33, 387-391, 1986.

6) Gadducci, A., Ferdeghini, M., Malagnino, G., Prontera, C., Fanucchi, A., Annicchiarico, C., Bianchi, R., Fioretti, P. and Facchini, V.: Elevated serum levels of neopterin and soluble interleukin-2 receptor in patients with ovarian cancer. Gynecol. Oncol., 52, 386-391, 1994.

7) Hausen, A., Fuchs, D., Konig, K. and Wachter, H.: Determination of neopterine in human urine by reversed-phase high-performance liquid chromatography. J. Chromatogr., 227, 6170, 1982.

8) Hahn, T. and Levin, S. : The interferon system in patients with malignant disease. J. Interferon Res., 2, 97-102, 1982.

9）橘 正人, 小倉雄太, 関根智久, 対馬敬夫, 大塚勝 幸, 高嶋一敏, 福島松郎：癌患者の血清中 Interferon 活性と免疫パラメーターとの相関について. Oncologia, 21, 123-126, 1988.

10) Fuchs, D., Hausen, A., Huber, C., Reibnegger, G. and Wachter, H.: Urinary neopterin in the diagnosis and follow-up of neoplasia: A biochemical parameter to detect cell-mediated immune response. Tumor Biology, 5, 199-209, 
1984.

11) Luzmits, R., Ludwig, H., Legenstein, E., Szekeresz, T., Kratslik, C. and Hofbauer, J. : Neopterin as tumor marker: Serum and urinary neopterin concentrations in malignant diseases. J. Clin. Chem. Clin. Biochem., 24, 119 $-124,1986$.

12) Aulitzky, W., Frick, J., Fuchs, D., Hausen, A., Reibnegger, G. and Wachter, H. : Significance of urinary neopterin in patients with malignant tumors of the genitourinary tract. Cancer, 55, 1052-1055, 1985.

13) Fuith, L.C., Dapunt, O., Hetzel, H., Reibnegger, G. and Wachter, H. : Second-look operation in women with ovarian cancer: Concentrations of neopterin in urine and CA 125 in serum at second-look laparotomy. Tumor Diagn. Ther., 11, 147-151, 1990.

14) Gunter, W., Kronberger, P., Conrad, F., Bodner, E., Wachter, H. and Reibnegger, G. : Neopterin and prognosis in patients with adenocarcinoma of the colon. Cancer Res., 53, 260-265,
1993.

15) Asano, T., Uwatoko, N., Tsuji, A., Nakajima, F., Hayakawa, M. and Nakamura, H. : Neopterin as a prognostic factor in renal cell cancer patients : seven year follow-up. J. Urol., 155, 584A, 1996.

16) Reibnegger, G., Fuchs, D., Hausen, A., Werner, E.R. and Wachter, H.: Activated macrophages and cancer. Lancet, 20, 1439, 1987.

17) Bichler, K.H., Kleinknecht, S. and Strohmaier, W.L. : Immune status and immune therapy of renal cell carcinoma. Urol. Int., 45, 269-283, 1990.

18) Ziegler, I., Hamm, U. and Berndt, J. : Participation of pterins in control of lymphocyte stimulation and lymphoblast proliferation. Cancer Res., 43, 5356-5359, 1983.

19) Horn, Y., Zeidman, J.L. and Heller, A. : Serum intrerferon as a biological marker in malignant tumors. Oncology, 42, 164-168, 1985. （1996年4月15日受付，9月9日受理） 